\title{
The Influences of Audio Visual Media and Vocabulary Mastery towards English Learning Achievement of EFL University Students
}

\author{
Tubagus Zam Zam Al Arif ${ }^{1}$ \\ ${ }^{1}$ Universitas Jambi, Indonesia \\ email: zamzam@unja.ac.id
}

\begin{abstract}
This study was an attempt to determine the impact of interaction between teaching media and vocabulary mastery towards students' learning achievement in colleges of education at Jambi University. This is a quasi-experimental study with non-equivalent control and experimental group design. Based on the test for normality, homogeneity, and analysis of variance to the data students' achievement score of experiment class can be concluded that, there are significant differences of learners' achievement between before and after treatment in experimental class using audio-visual media. Then, there are significant differences between the learners' vocabulary mastery on their learning achievement. The result of this study showed; 1 . There is a significant effect between teaching media toward learners' achievement. Test result obtained that p-value $0,015(<0,05) 2$. Vocabulary mastery gave the significant effect to the learners' achievement. Test result obtained that $\mathrm{p}$-value for vocabulary mastery is $0,000(<0,05)$. 3 . There is no interaction influence between the teaching media and vocabulary mastery towards learners' achievement. Test result retrieved that $p$-value is $0,948(>0,05)$.
\end{abstract}

Keywords: Audio Visual Media, Vocabulary, Learning Achievement

\begin{abstract}
Abstrak
Penelitian ini mencoba untuk menguji pengaruh dari hubungan perbedaan antara media pembelajaran dan penguasaan kosakata terhadap hasil belajar mahasiswa pada Fakultas Keguruan dan Ilmu Pendidikan di Universitas Jambi. Penelitian merupakan penelitian quasieksperimen dengan grup eksperimen dan grup kontrol. Dimana kelas eksperimen diberi perlakuan menggunakan media audio visual, sedangkan kelas control di beri perlakuan menggunakan cara konvensional (tanpa media audio visual). Berdasarkan hasil tes normalitas, homogenitas, dan analisis of varians terhadap nilai hasil belajar mahasiswa pada kelas eksperimen, dapat disimpulkan bahwa terdapat perbedaan yang signifikan hasil belajar mahasiswa sebelum dan sesudah diberikan perlakuan menggunakan media audio visual. Hasil dari penelitian ini menunjukkan bahwa; 1 . Terdapat pengaruh yang signifikan antara media pembelajaran terhadap nilai hasil belajar mahasiswa. Hasil tes menunjukkan nilai signifikansi sebesar 0.015 (<0.05). 2. Penguasaan kosakata memberikan pengaruh yang signifikan terhadap nilai hasil belajar mahasiswa, dengan nilai signifikansi sebesar 0.000 (< 0.05). 3. Tidak ada pengaruh interaksi antara media pembelajaran dan penguasaan kosakata
\end{abstract}


secara bersama-sama terhadap nilai hasil belajar mahasiswa, didapatkan nilai signifikansi sebesar 0.948 (>0.05).

Kata Kunci: Media Audio Visual, Kosakata, Hasil Belajar

\section{INTRODUCTION}

In the context of teaching English as a foreign language, it means that teaching English to the learners with different language, or in other words, the learners did not use English in their daily life. When teaching a language, teachers actually have two purposes; insure fluency and accuracy in all language skills. There are four language skills that the learners should acquire namely, listening, reading, speaking, and writing. And there are also language components they must master, that are vocabulary, pronunciation, and structure.

In teaching English language to EFL learners, teachers have the important role to make the learners understand even to make the learners master the language skills. Teachers can use so many ways to attract the learners' interest. One of the ways that teachers can do in teaching and learning process is using teaching media especially audio visual media. The use of audio visual media can make the teaching and learning process effective and efficient.

In the TEFL context at the university students, it may be useful to investigate particular strategies to help the students develop their language skills, so that they will be successful in their learning achievement. For this reason, using Audio Visual Media in teaching English has been believed effective to improve students' learning achievement. In this sense, Sugiharto (1994) states that instructional media can be used in the teaching of English, because they can activate and stimulate the students' interest in studying
English, lessen verbalism, and make the acquisition of the result of learning permanent.

Media can be defined as mediator or conductor which deliver the information from the transmitter to the receiver. In the teaching and learning process media are defined as all the objects that mediate the learning process. According to Van Els et al. (1984), media are all aids which may be used by teachers and learners to attain certain educational objectives. Heinich (1993) also states that media are considered as instructional media when they carry messages with an instructional purpose, to facilitate communication. Moreover, Suleiman (1988) asserts that instructional media are the media that bring information or messages from the information resources I sender (teachers) to the receivers (students). He further states that the instructional media are intended to increase the learning outcome. However, it must be remembered that in the use of instructional media, it is important for the teachers to have certain ability and skill to use the media effectively and efficiently.

Generally, there are three kinds of teaching media. They are audio, visual, and audio-visual media. Audio media are media that can be listened to, while visual media are media that can be seen. The teaching media that involve the senses of sight and hearing are named as audio-visual media (Kasbolah, 1993;57)

Furthermore, Sukiman (2012) states that media consists of four kinds, the first is audio media such as; recording, taperecording, multitrack recording, digital, recording, and radio. The second is visual 
media such as; picture, photo, sketch, chart, graphic, board, flanel board, bulletin board, poster, cartoon, map, globe, OHP, and modul. The third is Audio-Visual media such as; video, film, and television. And the last is computer such as; power-point, internet.

Mayer (2001) defines multimedia as the combination of various digital media types, such as text, image, sound, and video, into an integrated multi-sensory interactive application or presentation to convey a message or information to an audience. He also describes potential benefits of multimedia that humans possess visual and auditory information processing capabilities. Ivers and Baron (2002) state that multimedia allows the understanding of a topic to be conveyed in a variety of ways and provides students with opportunities to explain their ideas to others. It also provides students with a medium for communication and offers them new insights into organizing and evaluating information. Besides, multimedia has the potential to change the roles of teachers and students and the interactions between them by allowing students to create their own interpretations of information. Reddy (2008:26) states that audio visual education consists of the uses of interactional devices such as film projectors, radio, television, charts, posters, models, field trips etc.

According to Madhuri (2013), AVM tools for students can improve speaking skills several times over, more than other methods. AVM can be defined as stimulating materials and devices which aid sound and sight in teaching to facilitate learning by students by activating more than one sensory channel.

Bavaro (1989), as cited in Mutar (2009), states that AVM are important in learning technical EFL because they can stimulate learners and encourage them to learn a foreign language. Technical AVM can communicate facts and ideas through the eyes and ears to the mind and to the emotions. Technical AVM include computers, videos, overhead projectors, instruments and tools of industrialization (Bavaro, 1989).

Potosi et al. (2009) did a research to see the impact of video on listening skill and towards video. The mission of the program was to prepare professional English teachers to increase the educative level of the region in the learning of English as a foreign language. Safarali and Hamidi (2012) did a study on the impact of videos presenting speakers' gestures and facial clues on Iranian EFL learners' listening comprehension. They conclude that using videos presenting speakers' gesture and facial clues has a significant effect on the EFL learners' listening comprehension. Ismaili (2013) did a different study to observe the effect of movies to make learners to be more involved in reading activities. The study aimed to explain and analyze the effectiveness of using movies on improvement of language competence and performance of learners in academic settings. Also the study aimed to examine whether movies may provide as a bridge between learning skill and language objectives or performances of learners. Asadi and Berimani (2015) considered a study on the usefulness of audio-visual aids in ELT in Iranian context. They found how the use of audio visual materials helps the language teacher and the learners in EFL classroom at high school level. The result of their study indicates that using audio-visual aids in language teaching is helpful for both the teachers and the students in improving students' language achievement and students' motivation.

Vocabulary is one of the important language components that must be mastered 
by the students. Learning vocabulary is one of the important steps of learning a foreign language, because the students never learn vocabulary acquisition. Whether in native language, second language, or foreign language the acquisition of new vocabulary is a continual process. Many methods can help the students acquire new vocabulary. By mastering vocabulary the students are hoped to be able to communicate each other and apply their vocabulary in writing (Wahyuni, S. 2018).

The goals of education especially of teaching English as a foreign language is the learners will be able to read, express ideas, get information, and develop sentences in written language (Al Arif, 2017). To achieve the goals, the learners need to master a lot of vocabulary. According to Schmitt (1997:40), vocabulary is one of the most important skills in language".

Based on the background of the problem above, the writer assumes that teaching media and vocabulary mastery has an important role on students' learning achievement. The writer is interested to conduct the research about the effect of audio visual media and vocabulary mastery towards students' learning achievement. When the writer did preliminary research to the EFL students at colleges of education of Jambi University, the writer found that the students got difficulties in mastering English language skills. The difficulties were caused by lack of vocabularies, the students were bored in learning process, the students got difficulties in mastering vocabularies, the instructional media used was not appropriate to the material, and the teaching and learning process was not attractive and communicative.

Therefore, the writer assumes that there are some effects of teaching media and students' vocabulary mastery on the students' learning achievement. It means that if the teachers apply appropriate media in teaching and learning process, and the students master vocabulary well, they will have good learning achievement. Based on the theories and assumption above, the purposes of this research are as follow:

1. to find out if there are some significant difference between teaching media towards students' learning achievement.

2. to find out if there are some significant difference between students' vocabulary mastery towards students' learning achievement.

3. to find out if there are some significant interaction of teaching media and students' vocabulary mastery towards students' learning achievement.

\section{METHOD}

In this research, the researcher applied quasi experimental with non-equivalent control group design. The purpose of the research is to find out the significant effect of audio visual media and vocabulary mastery towards the students' learning achievement. There are two groups in this research; experimental group and control group. Both groups were given pre-test and post-test in which the pre-test was administered to measure prior competence of students' before treatment, vocabulary test to measure their vocabulary mastery, while the post-test was administered to measure their learning achievement after treatment.

The population of this research is the undergraduate students of Jambi University. The samples of this study were taken from the second semester students of math education who have been taking English subject at Jambi University. It consists of 4 classes with the total number 146 students. To decide samples in this research, the 
researcher applied purposive sampling technique, because the population consists of four classes that are R001, R002, R003, and R004. The sample of the research was taken two classes which represent the experimental group (R001) with 38 students and control group (R002) with 38 students. The total number of samples was 76 students.

In this research the writer used a set of test as the instruments to collect data. Arikunto (2002:127) defines a test as a set of questions, experience, or other means to measure skills, knowledge, intelligence, achievement, and aptitude of an individual or group. The instrument used in this research was vocabulary test and English test. The vocabulary test is multiple choice that consists of 20 questions. And for the English test, the researcher gave the students English for Academic Purposes test which consists of reading, structure and written expression, and tenses. The English test was done twice before and after giving the treatment.

The treatment was done using audio visual media, in this case the researcher played videos as the treatment in experimental class that are appropriate with the topic. In determining and choosing appropriate videos, the researcher makes it suitable with students' need, level, and reinforces the use of audio-visual media by combining them with the relevant techniques, and considering the time in using audio-visual media.

The data were analyzed quantitatively through Analysis of variance with SPSS 23. The data of teaching media in form of nominal data that is 1 for audio visual media and 2 for conventional media. For the data of vocabulary mastery the researcher used scoring scale by using three classifications; they are 1 for high, 2 for medium, and 3 for low vocabulary mastery.
And the data of students' learning achievement are the score of students' posttest.

\section{FINDING AND DISCUSSION}

a. Validity Test : To get validity of the test, the test instrument was suited with the material taught to the students. In other words, the researcher made the test based on the material in the syllabus used for the Second Semester Students of English Education Study Program.

\section{b. Normality Test}

Table 1. Normality Test.

One-Sample Kolmogorov-Smirnov

Test.

\begin{tabular}{|cc|c|}
\hline & & $\begin{array}{c}\text { Achieve } \\
\text { ment }\end{array}$ \\
\hline & & \\
Normal & $\mathrm{N}$ & Mean \\
Parameters ${ }^{\mathrm{a}, \mathrm{b}}$ & Std. & 72.9737 \\
& Deviation & 4.83866 \\
Most Extreme & Absolute & .231 \\
Differences & Positive & .231 \\
& Negative & -.152 \\
Test Statistic & .231 \\
Asymp. Sig. (2-tailed) & $.072^{\mathrm{c}}$ \\
\hline
\end{tabular}

a. Test distribution is Normal.

b. Calculated from data.

c. Lilliefors Significance Correction.

The normality data test of Posttest scores was used kolmogorov-smirnov test, the result showed that the posttest sig. score of experimental group and the posttest of control group was $0.072>0.05$. It means that the data of posttest were in normal distribution.

c. Homogenity Test

Table 2. Homogeneity Test

\section{Levene's Test of Equality of Error Variances ${ }^{\mathrm{a}}$.}

Dependent Variable:

Learning_Achievement.

\begin{tabular}{|r|r|r|r|}
\hline F & df1 & df2 & Sig. \\
\hline 4.460 & 5 & 70 & .059 \\
\hline
\end{tabular}


Tests the null hypothesis that the error variance of the dependent variable is equal across groups.

a. Design: Intercept + Teaching_Media + Vocabulary + Teaching_Media * Vocabulary

The homogeneity test was used as a requirement of parametric test to decide whether the data were homogenous or not. In this study, to know the homogeneity of the data pretest and posttest of experimental and control group, the data were calculated using SPSS with levene's test, and the result showed that the sig. $0.059>0.05$.

d. Analysis of Variance

Table 3. Between Subject Factors.

Between-Subjects Factors.

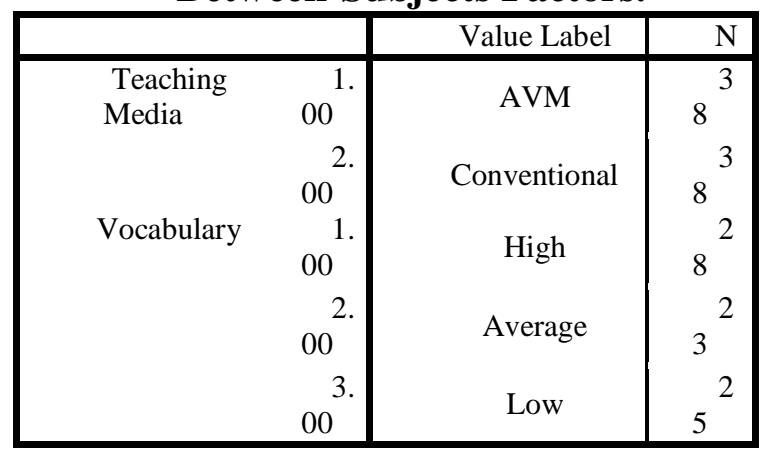

Table 4. Descriptive Statistics.

Descriptive Statistics

Dependent Variable:

Learning_Achievement.

\begin{tabular}{|cc|c|c|r|}
\hline $\begin{array}{r}\text { Teachi } \\
\text { ng_Media }\end{array}$ & $\begin{array}{c}\text { Voca } \\
\text { bulary }\end{array}$ & Mean & $\begin{array}{c}\text { Std. } \\
\text { Deviation }\end{array}$ & N \\
\hline AVM & High & 77.304 & 4.289 & 23 \\
& & 3 & 89 & \\
& Aver & 73.500 & 4.503 & 8 \\
& age & 0 & 97 & \\
& Low & 71.142 & 2.267 & 7 \\
& & 9 & 79 & \\
& Total & 75.368 & 4.698 & 38 \\
\hline Conven & High & 74.400 & 5.366 & 5 \\
tional & & 0 & 56 & \\
& Aver & 71.333 & 4.047 & 15 \\
& age & 3 & 34 &
\end{tabular}

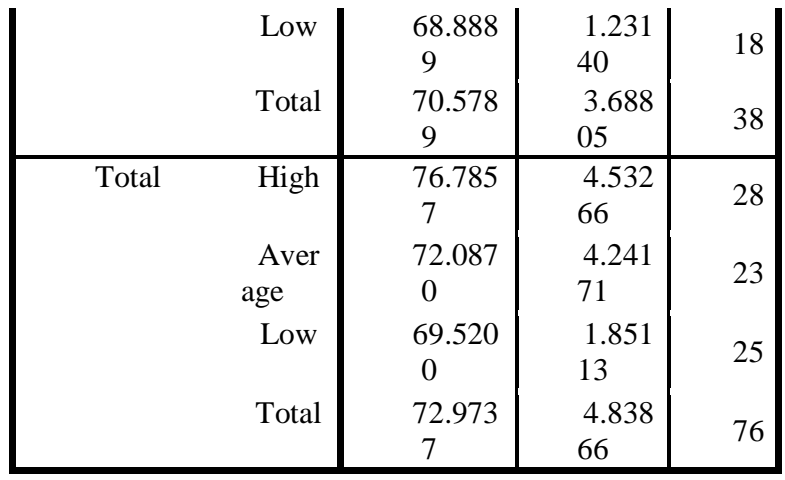

The data above shows that the total mean of experimental group is 75,36 , with high vocabulary mastery that is 77.30 , with medium vocabulary mastery that is 73,50 , and with low vocabulary that is 71,14 . That score is much higher than the control group which total mean score is only 72.97 with high vocabulary mastery that is 76,78 , medium vocabulary mastery that is 72,08 , and low vocabulary mastery that is 69,52 . It means that the experimental group can be declared as successful experiment. In other words, the experimental group taught with audio visual media got higher score than the control group taught with conventional media.

Table 5. Hypothesis Tests of Between Subjects Effects.

Tests of Between-Subjects Effects. Dependent Variable: Learning_Achievement.

\begin{tabular}{|c|c|c|c|c|c|}
\hline Source & $\begin{array}{c}\text { Ty } \\
\text { pe III } \\
\text { Sum of } \\
\text { Squares } \\
\end{array}$ & Df & $\begin{array}{l}\text { M } \\
\text { ean } \\
\text { Squar } \\
\text { e }\end{array}$ & $\mathrm{F}$ & Sig. \\
\hline \multirow{3}{*}{$\begin{array}{l}\text { Correct } \\
\text { ed Model } \\
\text { Interce } \\
\text { pt }\end{array}$} & $\begin{array}{r}807 \\
910^{a}\end{array}$ & 5 & $\begin{array}{r}16 \\
1582\end{array}$ & $\begin{array}{r}1 \\
1931\end{array}$ & \multirow[t]{2}{*}{.000} \\
\hline & 300 & & 30 & 2 & \\
\hline & $\begin{array}{c}829.56 \\
5\end{array}$ & 1 & $\begin{array}{c}0829 \\
565\end{array}$ & $\begin{array}{c}2212 . \\
267\end{array}$ & .000 \\
\hline Teachi & 84. & 1 & 84 & & .015 \\
\hline Vocabu & 308 & & $\begin{array}{r}.089 \\
15\end{array}$ & $\begin{array}{r}.253 \\
1\end{array}$ & \multirow{2}{*}{.000} \\
\hline lary. & .975 & 2 & 4.487 & 1.407 & \\
\hline ng_Media & 1.4 & & .7 & & \\
\hline$*$ & 35 & 2 & 18 & 053 & (940. \\
\hline Vocabulary & & & & & \\
\hline
\end{tabular}




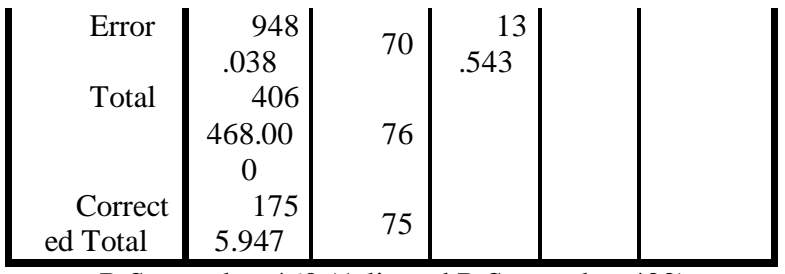

a. R Squared $=.460$ (Adjusted R Squared $=.422$ )

The score of analysis of variants showed that the score of teaching media is sig. $0.015<0.05$. It means that null hypothesis (H0) is rejected and (H1) alternative hypothesis is accepted. It proves that the significant difference in average (mean) of student's learning achievement taught by using audio visual media and students taught by conventional media is different significantly. And it also showed that there is a significant effect of using audio visual media towards students' learning achievement.

The score of vocabulary mastery is with sig. $0.000<0.05$. It means that null hypothesis (H0) is rejected and (H1) alternative hypothesis is accepted. It proves that the significant difference in average (mean) of students' learning achievement with high, medium, and low vocabulary mastery is different significantly. And it also showed that there is a significant effect of vocabulary mastery towards students' learning achievement.

The table shows that the score of vocabulary*Teaching Media is sig. $0.948>$ 0.05 . It means that null hypothesis $(\mathrm{H} 0)$ is accepted and (H1) is rejected. It means that teaching media (AVM) and vocabulary mastery towards students' learning achievement is not different significantly. Or in other words, there is not a significant interaction between teaching Media (AVM) and Vocabulary mastery towards students' learning achievement.

\section{CONCLUSION}

Based on the data obtained, the result of hypothesis testing and discussion of the result of this research, it can be summed up that there is a significant effect of audio visual media towards students'. The summary of ANOVA shows the sig. 0.015 $<0.05$. It means that null hypothesis $(\mathrm{HO})$ is rejected and (H1) is accepted. It proves that the difference in average (mean) of student learning outcomes that is taught by using audio visual media with students taught by conventional media is different significantly. Then the conclusion is that there is a significant difference between audio visual media towards students' learning achievement.

There is a significant effect of vocabulary mastery towards students' English learning achievement. It is proved by the mean difference of students' writing test outcomes of students who have high vocabulary mastery, medium vocabulary mastery, and the students with low vocabulary mastery. The summary of ANOVA shows that the sig. $0.000<0.05$. In other words, there is a significant difference on students' learning outcomes between students who have high vocabulary mastery, medium vocabulary mastery, and students with low vocabulary.

There is no significant effect of teaching media and vocabulary towards students' learning achievement. The summary of ANOVA shows that sig. $0.948>0.05$. in other words, there is no interaction between teaching media and vocabulary mastery towards students' learning achievement.

Based on the conclusion of the research, the following are suggestions to improve students' learning achievement of colleges of education students at Jambi University: 
1. Teacher should use proper and appropriate teaching media in teaching and learning process to achieve the learning goals.

2. Teacher should know and understand the obstacles of the students to improve their learning achievement.

3. Teacher should encourage students' vocabulary mastery by using attractive media in teaching and learning process.

This research has limitations therefore, for further study is suggested to investigate these aspects deeper and more details to improve EFL students' learning achievement.

\section{REFERENCES}

Al Arif, T. Z. Z. (2017). The Correlation between Students' Vocabulary Mastery and Their Ability in Writing Functional Text at SMAN 1 Bandar Lampung. Jambi-English Language Teaching. 2(1), 18-26.

Asadi, F., \& Berimani, S. (2015) The Effect of Audio-Visual Materials on Iranian Second Grade High School Students' Language Achievement. International Journal of Language and Linguistics. 3(2), pp. 69-75. doi: 10.11648/j.ijll.20150302.15

Bavaro, S. (1989). Audio/visual Aids: A Study of the Effect of Audio/Visual Aids on the Comprehension Recall of Students. (Unpublished Master's thesis). Kean College, Union, NJ.

Heinich, R., Molenda, M., and Russel, J. (1993). Instructional Media: and the New Technologies of Instruction. Canada: John Willy and Sons, Inc.

Ismaili, M. (2013). The effectiveness of using movies in the EFL classroom: A study at South East European
University. Academic Journal of Interdisciplinary Studies, 2(4), 121132.

Ivers, K., \& Baron, A. (2002). Multimedia Project in Education. Santa Barbara: ABC- CLIO LLC.

Kasbolah, K. (1993). Teaching Learning Strategy. I. Malang: IKIP Malang.

Madhuri, J.N. (2013). Use of Audio Visual Aids in Teaching and Speaking. Research Journal of English Language and Literature, 1(3), 108122.

Mayer, R. E. (2001). Multimedia Learning. Cambridge, UK: Cambridge University Press.

Mutar, S.S. (2009). The effect of using technical audio-visual aids on learning technical English language at technical institutes. Journal for Academic Studies, 8(15), 1-12.

Potosi, A., Jhoana, L., Loaiza, G., Andres, E., Garcia, L., \& Catalina, A. (2009). Using video materials as a teaching strategy for listening comprehension. Universidad Tecnológica dePereira

Reddy, R.J. (2008). Methods of Teaching. New Delhi: S.B Nangia.

Safarali, k. S. \& Hamidi, H. (2012). The impact of videos presenting speakers' gestures and facial clues on Iranian EFL learners' listening comprehension. International Journal of Applied Linguistics \& English Literature, 1(6), 106-114. doi:10.7575/ijalel.v.1n.6p.106

Schmitt, N., \& McCharty. M. (1997). Vocabulary: Description, Acquisition and Pedagogy. Cambridge, UK; Cambridge University Press.

Sugiharto, W. (1994). The Use of Visual Media in The Teaching of English in Public Junior High School in Kodya Malang. (Unpublished Thesis). Malang: FPBS IKIP Malang. 
J-SHMIC : Journal of English for Academic

Vol 7, No 1, February 2020

$E-I S S N=2641-1446, P-I S S N=2356-2404$

Sukiman. (2012). Pengembangan Media Pembelajaran. Yogyakarta: Pedagogia.

Suleiman, A.H. (1988). Media Audio-Visual untuk Pengajaran Penerangan dan Penyuluhan. Jakarta: PT. Gramedia.

Van Els, Theo et al. (1984). Applied Linguistics and the Learning and Teaching of Foreign Languages. New York: Chapman and Hall, Inc. 